\title{
ADSORPSI LOGAM BERAT MENGGUNAKAN ADSORBEN ALAMI PADA AIR LIMBAH INDUSTRI
}

\author{
Rivania Delaroza \\ Jurusan Teknik lingkungan, Fakultas Arsitektur Lanskap dan Teknologi \\ Lingkungan,Universitas Trisakti, Jakarta, Indonesia \\ Email Korespondensi : rivania08215049@std.trisakti.ac.id
}

\begin{abstract}
ABSTRAK
Penulisan ini dilakukan untuk mengurangi logam berat berat yang terdapat pada air limbah industri dengan menggunakan adsorben alami. Pada penulisan ini dilakukan metode batch. Pembuatan adsorben alami efektif dalam proses adsorpsi karena relatif aman terhadap lingkungan dan biaya yang dikeluarkan cukup murah. Pada proses pembuatan adsorben alami, adsorben harus diseragamkan ukurannya agar proses adsorpsi lebih efektif. Adsorben lebih efektif untuk mengadsorpsi apabila di aktivasi secara kimia dan secara fisik. Secara kimia dapat menggunakan larutan asam atau basa tergantung struktur adsorben. Menurut penelitian sebelumnya, untuk adsorben aktivasi yang paling efektif menggunakan larutan asam kuat dengan pengaruh waktu aktivasi. Setelah adsorben aktivasi, untuk menganalisis luas permukaan yang terbentuk dapat menggunakan metode Scanning Electron Microscopy (SEM). Proses adsorpsi memiliki pengaruh terhadap waktu kontak, pH, kecepatan pengadukan, massa adsorben, luas partikel. Beberapa penelitian telah membuktikan bahwa adsorben alami dapat menurunkan logam berat, seperti menggunakan kulit pisang, jerami, kitosan dan kulit udang. Melihat kemampuan adsorben alami yang telah dibuat dalam mengadsorpsi logam berat dapat menggunakan isoterm adsorpsi yang meliputi isoterm langmuir dan menggunakan isoterm freudlich
\end{abstract}

Kata kunci : Adsorpsi, Adsorben Alami, Isoterm Adsorpsi

\section{PENDAHULUAN}

Pencemaran logam berat sudah menjadi masalah lingkungan di dunia karena bisa terakumulasi ke dalam makanan dan dapat mennyebabkan masalah tidak hanya terhadap ekosistem tetapi juga masalah terhadap kesehatan manusia (Abbasi et al.2013). Salah satunya pencemaran akibat limbah tanpa diolah yang terjadi di Cicabe yang terletak di Desa Mandalajati,Bandung (Julita and Kamil,2018). Pada peneletian ini membuktikan bahwa adanya limbah terkontaminasi logam berat kromium. Logam berat umumnya bersifat karsinogenik dan merupakan zat yang beracun. Didalam zat pencemar perairan, logam berat sangat berbahaya bagi kehidupan mahluk hidup (Hossain et al. 2012). Terutama Senyawa tembaga berlebih di tubuh juga mempengarui pada penuaan,skizofrenia, penyakit mental, sirosis kecil India, wilson dan penyakit alzheimer (Hossain et al.2012).

Proses penghilangan logam berat yang telah dilakukan menggunakan beberapa cara alternatif salah satunya adalah proses adsorpsi. Adsorpsi adalah proses dimana molekul cairan menyentuh dan menempel ke permukaan padatan. Berbagai zat dapat digunakan sebagai adsorben untuk proses adsorpsi (Pratiwi and Prinajati, 2018). Pengolahan limbah zat warna dan logam berat dapat juga dilakukan dengan berbagai metode yaitu filtrasi, presipitasi kimia, ion exchange, adsorpsi dan sistem membran (Darjito et al. 2014). Metode adsorpsi memiliki beberapa kelebihan diantaranya adalah pengolahannya relatif sederhana, dan efesiensinya relatif tinggi, efektif serta tidak memberikan dampak buruk terhadap lingkungan (Hossain et al. 2012). 
Pada proses adsorpsi menggunakan adsorben dari bahan alami. Penggunaan adsorben alami ini dikarenakan karena relatif aman dan biaya yang dikeluarkan cukup murah. Hal ini terbukti dengan adanya beberapa penelitian terdahulu, seperti menggunakan kulit pisang (Vilardi et al. 2017)., jerami (Firdaus et al.2018), kulit kelapa (Nwodika and Onukwuli, 2014), kitosan dan kulit udang(Pratiwi and Prinajati, 2018)

\section{TINJAUAN PUSTAKA}

\section{Adsorpsi}

Adsorpsi melibatkan fenomena pelekatan permukaan. Dalam proses adsorpsi jika material biologis digunakan sebagai adsorben maka prosesnya dikenal sebagai biosorpsi. Proses ini melibatkan interaksi fase padat dan cair. Karena interaksi adsorben dan adsorbat, pertukaran ion dan menghilangkan spesies terlarut yang tidak diinginkan (Khan,A et al .2017). Adsorpsi biasanya dianggap sebagai proses pemisahan yang penting karena menurut secara teknologi, lingkungan dan biologis dalam operasi. Adsorpsi adalah proses pemisahan yang mendukung penghapusan polutan konsentrasi rendah dari volume besar proses, air limbah, dan air solusi. Sistem proses adsorpsi dapat berupa: gas-cair, cairancair, padat-cair dan gas padat (Nwodika and Onukwuli, 2014)

Proses dari adsorpsi dapat dibedakan menjadi dua proses ada yang disebut sebagai adsorpsi secara fisik dan adsorpsi secara kimia. Adsorpsi secara fisik erat kaitannya dengan gaya van der walls yang dimana proses bolak-balik jika ada kemampuan daya tarik menarik antara adsorben dan zat terlarut lebih besar dengan pelarutnya maka proses akan diadsorpsi di permukaan sedangkan adsorpsi secara kimia reaksi yang berlangsung antara zat padat dan zat terlarut yang sudah teradsorpsi (Mufrodi et al. 2008)

\section{Logam Berat}

Membuang limbah yang mengandung logam berat ke lingkungan menjadi masalah utama dalam permasalahan air yang tercemar. Hal ini menimbulkan dampak pada meningkatnya organisme yang mengandung polutan logam berat seperti pada biota laut, karang, dan beberapa keluarga alga atau rumput laut. Hal yang sangat memprihatinkan, konsumsi tinggi sumber makanan laut yang tercemar logam berat oleh manusia merupakan masalah penting bagi kesehatan manusia (Darjito et al 2014).

Pencemaran logam berat dapat merusak lingkungan antara lain adalah Merkuri $(\mathrm{Hg})$, Timbal (Pb), Arsen (As), Kadmium (Cd), Krom $(\mathrm{Cr})$, dan Nikel (Ni) (Suprabawati and Dwikora, 2016). Jenis logam berat utama diantara logam berat yang tersedia di perairan lingkungan Hidup merupakan logam $\mathrm{Cu}$. Logam $\mathrm{Cu}$ dapat masuk ke lingkungan dari kegiatan penambangan beberapa logam, dari unit industri yang membuat atau menggunakan logam $\mathrm{Cu}$ atau senyawa $\mathrm{Cu}$, dan dari sumber antropologi lainnya seperti tempat pembuangan limbah, air limbah domestik, pembakaran bahan bakar fosil dan limbah, produksi kayu dan produksi pupuk fosfat (Vilardi et al. 2017). Tembaga di dalam sistem darah dapat dihasilkan spesies oksigen bebas reaktif yang dapat merusak protein, lipid dan DNA (Brewer GJ,2007). Senyawa tembaga berlebih di tubuh juga mempengarui pada penuaan,skizofrenia, penyakit mental, sirosis kecil India, wilson dan penyakit alzheimer (Hossain et al. 2012).

\section{Adsorben Alami}

Beberapa adsorben alami yang telah dilakukan dapat mengadsorpsi logam berat. Salah satunya penelitian menggunakan kulit pisang dan jeruk sebagai adsorben untuk menghilangkan $\mathrm{Cu} 2+, \mathrm{Zn} 2+, \mathrm{Co} 2+, \mathrm{Ni} 2+$, dan $\mathrm{Pb} 2+$ dari air (Annadurai, G et al 2014). Residu kulit pisang dan jeruk bisa diproses dan dikonversi menjadi adsorben karena memiliki luas permukaan yang besar memilki potensi besar untuk menyerap kontaminan berbahaya seperti logam berat (Annadurai,G et al 2014). Keuntungan menggunakan 
adsorben alami pada proses adsorpsi mudah tersedia, biaya rendah, kesederhanaan untuk digunakan dan ramah lingkungan. Berikut beberapa penelitian adsorpsi yang menggunakan bahan-bahan alami (Hossain et al. 2012).

Tabel 1. Hasil Penelitian Adsorpsi Menggunakan Bahan Alami

\begin{tabular}{|c|c|c|}
\hline Judul Paper, Tahun & Penulis & Hasil Penelitian \\
\hline $\begin{array}{l}\text { Heavy metals adsorption by banana } \\
\text { peels micro-powder: Equilibrium } \\
\text { modeling by non-linear models, } 2017\end{array}$ & $\begin{array}{l}\text { Giorgio Vilardi, } \\
\text { LucaDiPalma, } \\
\text { NicolaVerdone }\end{array}$ & $\begin{array}{l}\text { - Kapasitas adsorpsi logam } \\
\text { berat } \mathrm{Cu} \text { sebesar } 12.85 \mathrm{mg} / \mathrm{g} \text {. } \\
\text { Sedangkan kapasitas adsorpsi } \\
\text { logam berat Pb sebesar } 10.9 \\
\mathrm{mg} / \mathrm{g}\end{array}$ \\
\hline $\begin{array}{l}\text { Removal of Copper from Water by } \\
\text { Adsorption onto Banana Peel as } \\
\text { Bioadsorbent, } 2012\end{array}$ & $\begin{array}{l}\text { M. A. Hossain, H. Hao Ngo, } \\
\text { W. S. Guo and T. V. Nguyen }\end{array}$ & $\begin{array}{l}\text { - Kapasitas adsorpsi logam } \\
\text { berat } \mathrm{Cu} \text { sebesar } 27,78 \mathrm{mg} / \mathrm{g} \\
\text { - Menggunakan Isoterm } \\
\text { Langmuir dan Freudlich } \\
\text { dengan R2 sebesar } 0,998\end{array}$ \\
\hline $\begin{array}{l}\text { Efficiency Enhancement of Banana } \\
\text { Peel for Waste Water Treatment } \\
\text { through Chemical Adsorption, } 2017\end{array}$ & $\begin{array}{l}\text { Atif Khan, Hassan Jived } \\
\text { Naqvi, Shabana Afzal, } \\
\text { Shaista Jabeen, Misbah } \\
\text { Iqbal, and Iram Riaz }\end{array}$ & $\begin{array}{l}\text { - Kulit pisang diaktivasi dengan } \\
\text { asam oksalat, asam } \\
\text { sulfat,natrium hidroksida. } \\
\text { Hasil menunjukan setelah } \\
\text { dianalisis dengan metode FT- } \\
\text { IR, natrium hidroksida lebih } \\
\text { baik mengadsorp daripada } \\
\text { dua asam lainnya. }\end{array}$ \\
\hline $\begin{array}{l}\text { Adsorption Isotherm Of Some Heavy } \\
\text { Metals in Water on Unripe dan Ripe } \\
\text { Peel of Banana, } 2010\end{array}$ & $\begin{array}{l}\text { Mintra Sirilet, Kamol } \\
\text { Maikrang }\end{array}$ & $\begin{array}{l}\text { - Kapasitas absorbsi yang } \\
\text { optimum berada pada pH } 4 \\
\text { dan } 5 \text { dengan konsentrasi } 40 \\
\text { mg/L dengan waktu } 20 \text { menit } \\
\text { menggunakan kulit pisang } \\
\text { mentah dan matang. } \\
\text { - Kapasitas yang diadsorp } \\
\text { logam Cd untuk kulit tidak } \\
\text { matang } 1,630 \mathrm{mg} / \mathrm{g} \text { dan yang } \\
\text { matang } 2,8810 \mathrm{mg} / \mathrm{g} \\
\end{array}$ \\
\hline $\begin{array}{l}\text { Adsorption of Textile Dye by } \\
\text { Activated Carbon Made from Rice } \\
\text { Straw and } \\
\text { Palm Oil Midrib, } 2017\end{array}$ & $\begin{array}{l}\text { M. Lutfi Firdaus, Noli } \\
\text { Krisnanto, Wiwit Alwi, } \\
\text { Ronald Muhammad and M. } \\
\text { Allan } \\
\text { Serunting }\end{array}$ & $\begin{array}{l}\text { - Kapasitas adsorpsi pewarna } \\
\text { maksimum jerami padi dan } \\
\text { karbon aktif pelepah kelapa } \\
\text { sawit adalah 55,86 dan 69,44 } \\
\text { mg / g. } \\
\text { - Adsorpsi menggunakan } \\
\text { karbon aktif pengolahan air } \\
\text { limbah tekstil karena dapat } \\
\text { menghilangkan hingga 95\% }\end{array}$ \\
\hline $\begin{array}{l}\text { Adsorption Of Nickel(Ii) Ions From } \\
\text { Aqueous Solution Using } \\
\text { Banana Peel And Coconut Shell,2018 }\end{array}$ & $\begin{array}{l}\text { Babatope Olufemi, Omolola } \\
\text { Eniodunmo1 }\end{array}$ & $\begin{array}{l}\text { - Kulit kelapa dan kulit pisang } \\
\text { mampu menghilangkan logam } \\
\text { Nikel sebesar } 75,59 \% \text { dan } \\
77,8 \% \text { pada suhu } 20^{\circ} \mathrm{C} \\
\end{array}$ \\
\hline $\begin{array}{l}\text { Adsorption Of } \mathrm{Cu}, \mathrm{As}, \mathrm{Pb} \text { And } \mathrm{Zn} \mathrm{By} \\
\text { Banana Trunk. } 2016\end{array}$ & $\begin{array}{l}\text { Nurzulaifa Shaheera Erne } \\
\text { Mohd Yasim, Zitty Sarah } \\
\text { Ismail, Suhanom Mohd } \\
\text { Zaki, Mohd Fahmi Abd Azis }\end{array}$ & $\begin{array}{l}\text { - Persen adsorpsi untuk logam } \\
\mathrm{Cu}, \mathrm{As}, \mathrm{Pb} \text { and } \mathrm{Zn} \text { dengan } \mathrm{pH} \\
6 \text { dan } 100 \text { menit pada berat } \\
\text { adsorben } 8 \text { gram sebesar } \\
95.80 \%, 75.40 \%, 99.36 \\
\% \text { and } 97.24 \%\end{array}$ \\
\hline $\begin{array}{l}\text { Adsorption Study of Kinetics and } \\
\text { Equilibrium of Basic Dye on Kola Nut }\end{array}$ & $\begin{array}{l}\text { Chekwube Nwodika } \\
\text {,Okechukwu Dominic }\end{array}$ & $\begin{array}{l}\text { - Karbon aktif yang dihasilkan } \\
\text { Kola nut yang diaktivasi } \\
\end{array}$ \\
\hline
\end{tabular}




\begin{tabular}{|l|l|l|}
\hline Judul Paper, Tahun & Penulis & \multicolumn{1}{|c|}{ Hasil Penelitian } \\
\hline Pod Carbon,2017 & Onukwuli & $\begin{array}{l}\mathrm{H}_{2} \mathrm{SO}_{4} \text { dan Kola nut yang } \\
\text { diaktivasi CaOH dapat } \\
\text { digunakan secara efisien }\end{array}$ \\
& & $\begin{array}{l}\text { untuk menghilangkan } \\
\text { pewarna fuchsine dasar } \\
\text { - Kola nut yang teraktivasi } \\
\end{array}$ \\
& & $\begin{array}{l}\text { asam lebih baik dibandingkan } \\
\text { basa. Dapat menghilangkan } \\
\text { lebih dari 95\% Fuchsine basic }\end{array}$ \\
\hline
\end{tabular}

\section{PENUTUP}

Dari hasil karya ilmiah menunjukan bahwa adsoben alami memiliki kapasitas tinggi, ekonomis dan adsorben berbiaya rendah untuk menghilangkan logam berat. Hal ini terlihat dari beberapa penelitian yang telah dilakukan sebelumnya.

\section{DAFTAR PUSTAKA}

Abbasi, Z., Alikarami, M., Nezhad, E.R., Moradi, F., Moradi, V., 2013. Adsorptive Removal of $\mathrm{Co} 2+$ and Ni2+ by Peels of Banana from Aqueous Solution. Universal Journal of Chemistry, Volume 1(3), pp. 90-95

Andrew R., Biesinger,K., Glass,G.2014. Effects of inorganic complexing on the toxicity of copper to Daphnia magna, Water R es . 11 (3) 309-31 5.

Annadurai,G*, Juang ,R.S. ** and Lee, D.J. 2014. Adsorption Of Heavy Metals From Water Using Banana And Orange Peels. Water Sciences And Technology.

Brewer GJ, "Iron and copper toxicity in diseases of aging, particularly atherosclerosis and Alzheimer's disease”, Exp. Biol. Med., vol. 232, 2007, pp. 323-35.

Darjito,Darjito, Purwonugroho Danar,and Ningsih ,Rumiati. 2014.The Adsorption of Cr(VI) Ions Using Chitosan-Alumina Adsorbent. J. Pure App. Chem. Res. 3 (2), 53-61

Emelda, Lisanti, Putri,Suhardini Martiana and Ginting ,Simparmin Br.. 2013. Pemanfaatan Zeolit Alam Teraktivasi untuk Adsorpsi Logam Cr3+. Jurusan Teknik Kimia, Fakultas Teknik, Universitas Lampung. Vol. 9, No. 4, Hlm. 166 - 172

DOI: http://dx.doi.org/10.23955/rkl.v9i4.1229

Firdaus, Lutfi ,et al .2018. Adsorption of Textile Dye by Activated Carbon Made from Rice Straw and Palm Oil Midrib. Aceh Int. J. Sci. Technol., 6(1),1-7

DOI: $\underline{10.13170 / a i j s t .6 .1 .5502}$

Hossain,M. A., Ngo, H. Hao, W. S. Guo and Nguyen,T. V.. 2012. Removal of Copper from Water by Adsorption onto Banana Peel as Bioadsorbent. Int. J. of GEOMATE, Vol. 2, No. 2 (Sl. No. 4), pp. 227-234

Julita, Elsa Try , Kamil, Idris Maxdoni.2018. Mathematical Model To Identify Heavy Metal In Irrigation Channel From Cicabe Final Disposal Site. Indonesian Journal of Urban and Environmental Technology. Volume 2, Number 1, Page 1 - 13,

DOI : Http://Dx.Doi.Org/10.25105/Urbanenvirotech.V2i1.3530

Khan,A, Naqvi ,Hassan Jived, Afzal ,Shabana, Jabeen ,Shaista, Iqbal,Misbah, and Riaz ,Iram.2017.Efficiency Enhancement of Banana Peel for Waste Water Treatment through Chemical Adsorption. Proceedings of the Pakistan Academy of Sciences. A. Physical and Computational Sciences 54 (3): 329-335 
Kurniawan, Hendra and Notodarmojo, Suprihanto.2010. The Use Of Rice Straw To Eliminate Waste Color Textile Industry Color Index Reactive Orange 84. Jurnal Teknik Lingkungan Volume 16 Nomor 1, April 2010 (hal. 82-92)

Ind. Eng. Chem. Res. 50 (6) (2011) 3446-34 51

Mufrodi,Zahrul, Widiastuti,Nur, Kardika,Ranny Cintia.2008.Adsorpsi Zat Warna Tekstil Dengan Menggunakan Abu Terbang (Fly Ash) Untuk Variasi Massa Adsorben Dan Suhu Operasi. Teknik Kimia, Fakultas Teknologi Industri, Universitas Ahmad Dahlan. ISBN : 978-979-3980-15-7

Nwodika ,Chekwube and Onukwuli ,Okechukwu Dominic. 2017.Adsorption Study of Kinetics and Equilibrium of Basic Dye on Kola Nut Pod Carbon. GU J Sci 30(4): 86102

copper and lead from river water: Preconcentration of metal ions with a fruit waste,

Olufemi,Babatope and Eniodunmo,Omolola. 2018. Adsorption Of Nickel(Ii) Ions From Aqueous Solution Using Banana Peel And Coconut Shell. International Journal of Technology (2018) 3: 434-445

Pratiwi, R., Prinajati, D.P.S. 2018. Adsorption for lead removal by chitosan from shrimp shells.Indonesian Journal of Urban and Environmental Technology. 2(1) : 35-46

DOI : http://dx.doi.org/10.25105/urbanenvirotech.v2i1.3554

Sirilert,Mintra and Maikrang Kamol.2018.Adsorption Isotherm of Some Heavy Metals in Water on Unripe and Ripe peel of banana. Naresuan University Journal. 26(1)

Suprabawati,Anggi dan Dwikora,Dewi Dewanti. 2016.Serbuk Kulit Pisang Tanduk (Musa)"Horn” Ijuk Enau Dan Serbuk Sabut Kelapa Sebagai Bioadsorben Logam Berat Cd (Ii) Dan Penjernih Air. Jurnal Ilmiah Farmasi, Jun 2016, 4(1), 37-4

Vilardi,Giorgio, DiPalma ,Luca and Verdone,Nicola. 2017.Heavy metals adsorption by banana peels micro-powder: Equilibriummodeling by non-linear models. Chinese Journal of Chemical Engineering.

DOI : http://dx.doi.org/10.1016/j.cjche.2017.06.026

Yasim, Nurzulaifa Shaheera Erne Mohd,et al.2016. Adsorption Of Cu, As, $\mathrm{Pb}$ And $\mathrm{Zn} \mathrm{By}$ Banana Trunk. Malaysian Journal Of Analytical Sciences. Vol 20 No $1: 187$ - 196 